PRISCILA LEMES (10 orcid.org/0000-0002-0918-5158) and CHRISTINE STRÜSSMANN* (10 orcid.org/0000-0001-9880-9489) Universidade Federal de Mato Grosso, Cuiabá, Brazil

MARIA COELHO (ㅇ orcid.org/0000-0002-4430-6111), GUARINO COLLI* (10 orcid.org/0000-0002-2628-5652), ANA DEL PRETTE (10 orcid.org/0000-0001-6908-5020), BEATRIZ VASCONCELOS (D orcid.org/0000-0003-0101-8969) and REUBER BRANDÃO* (ㅇo orcid.org/0000-0003-3940-2544) Universidade de Brasília, Brasília, Brazil

E-mail reuberbrandao@gmail.com

${ }^{*}$ Also at: Brazilian Red List Authority group, supported by the National Center for Reptiles and Amphibians Research and Conservation, Chico Mendes Institute for Biodiversity Conservation, Brasília, Brazil

\section{New and increasing threats may have significant impact on Jamaica's black-billed parrot Amazona agilis}

The black-billed parrot Amazona agilis, currently categorized as Vulnerable on the IUCN Red List, is endemic to Jamaica, with an estimated $95 \%$ of its population believed to reside in Cockpit Country. Cockpit Country is a dense, montane, tropical forest in the west-central uplands of the island, with high levels of endemism, and traditional and Indigenous communities living on the periphery. There have been few studies-none recent-of the distribution and abundance of the area's extant species owing to the density of the forest, its remoteness, and the largely unnavigable terrain, particularly in the forest reserve.

Recent research explored the catch yields of traditional parrot hunting in Cockpit Country (Gibson, 2020, Journal of Ethnobiology, in press). Statistics for the 2018 and 2019 hunting seasons (July-September) suggest a significant decline in the black-billed parrot population, with the total take $<5 \%$ of that of the yellow-billed parrot Amazona collaria, also endemic to Jamaica. There are, however, limitations to this study. Yellow-billed parrots were used more extensively as lures during hunts than were black-billed parrots, which could account for the differences in total takes. Large flocks of black-billed parrots have been reported by Indigenous communities in fruit trees around villages, months after the hunting season. Such spatial and temporal changes in distribution may be a response to diminishing food sources within the forest interior, where parrot hunting is traditionally practiced. Although more research is needed to determine the distribution and abundance of the black-billed parrot, a number of emerging and increasing threats could place more pressure on this species, which is a habitat specialist, than on its wider-ranging congener.
Two of the three black-billed parrots caught by hunters in 2019 appear to be hybridized with the Puerto Rican parrot Amazona vittata. The 2019 hunting season also marked the first observation by the hunters, in the 42 years since the eldest living hunter began hunting, of the Near Threatened plain pigeon Patagioenas inornata. This reinvigorates ongoing debates around the possible migration of the Puerto Rican subspecies of the plain pigeon to Jamaica, where some scholars and conservationists believe it may be being misidentified as the Jamaican subspecies. The two hybridized black-billed parrots may be emerging evidence of non-migrant species from neighbouring Caribbean islands arriving in Cockpit Country. There are plans for research to investigate this, using GPS tracking. Any increased competition from such arrivals could become an additional threat to the black-billed parrot.

Currently known threats to the black-billed parrot include nest depredation by the Jamaican boa Chilabothrus subflavus. But, as part of a community-based conservation project conducted by the authors, camera traps installed in previously unmapped areas of the forest interior have recorded feral cats, black rats and mongooses. These small mammals could also be potentially responsible for blackbilled parrot nest predation, particularly in the forest interior, where the black-billed parrot breeds.

\section{Robert Cawley, Cornell Wright, Oral White and Donnell Rowe Accompong Maroon Town, St Elizabeth, Jamaica}

LYDIA GIBSON (이 orcid.org/0000-0003-3883-8485)

Department of Anthropology, University College London, London, UK. E-mail lydia.gibson.14@ucl.ac.uk

\section{The Whitley Awards 2020}

The Whitley Fund for Nature has announced the six conservation leaders, from six different countries, receiving a 2020 Whitley Award of GBP 40,00o each in 1 year of project funding. In addition, the Whitley Gold Award of GBP 60,000 was presented to 2008 Whitley Award winner Patricia Medici of Instituto de Pesquisas Ecológicas (Institute for Ecological Research), Brazil, for her work to conserve the lowland tapir in the Atlantic Forest, Pantanal, Cerrado and Amazon biomes. In light of the COVID-19 pandemic, the Whitley Awards Ceremony, the flagship event of the UK-based charity, has been postponed until later in the year.

The 2020 Whitley Award Winners are Abdullahi Hussein Ali, Kenya (A landscape-level approach to conserve the hirola antelope); Gabriela Rezende, Brazil (Connecting populations of black lion tamarins in the Atlantic Forest); Phuntsho Thinley, Bhutan (Stepping up patrols to preserve the Endangered alpine musk deer); Jeanne Tarrant, South 
Africa (A country-wide strategy for South African amphibians); Rachel Ikemeh, Nigeria (Advancing participatory conservation action for rare chimpanzees); and Yokyok Hadiprakarsa, Indonesia (Saving the last stronghold of the helmeted hornbill).

To date, the charity has given GBP 17 million in conservation funding to more than 200 conservation leaders in over 80 countries. The Whitley Award was one of the first awards to be given in recognition of effective conservation leadership in the Global South. Twenty-seven years on, the need for recognition of grassroots leadership has never been stronger. The fund supports emerging country nationals whose work is rooted in community involvement and who are best placed to implement change on-theground, leading projects that are pragmatic, science-based and impactful.

The commitment of the Whitley Fund for Nature to conservation leaders is long-term, with winners benefiting from lifelong membership of a global network of Whitley Award alumni. This facilitates access to the Continuation Funding programme-further funding to scale up their work and bring about positive change for threatened species and communities. Over half of Whitley Award winners go on to win Continuation Funding grants of up to GBP 100,000 over up to 2 years. Depending on the charity's fundraising, Whitley Fund for Nature aims to give GBP 700,000 in Continuation Funding each year. A recordbreaking GBP 1.2 million was given in 2019. Many winners become some of the most influential conservationists in their field, with projects making an impact from the grassroots to the national and international levels. For more information on the Whitley Fund for Nature, the Whitley Awards and the winning projects, visit whitleyaward.org.

JANICE LAW (๑ orcid.org/0000-0001-5328-5634) Whitley Fund for Nature, London, UK. E-mail janice@whitleyaward.org 